\title{
Toxicological and immunohistochemical testing of honeybees after oxalic acid and rotenone treatments*
}

\author{
Aleš GREGORC, Maja Ivana SMODIŠ ŠKERL \\ Agricultural Institute of Slovenia, Hacquetova 17, 1001 Ljubljana, Slovenia
}

Received 10 April 2006 - Revised 14 November 2006 - Accepted 20 December 2006

\begin{abstract}
Bees removed capped brood and young larvae from combs at a greater rate after a rotenone treatment than after an oxalic acid (OA)/sucrose treatment. Rotenone (1\%) caused $75.2 \%$ of capped brood to be removed, OA (3\%) $18.7 \%$ and a control treatment, $13.3 \%$. Caged worker bees treated with a $1 \%$ rotenone powder, a 3\% OA or with a control solution had mortality rates of $10.9 \%, 5.1 \%$ and $1.9 \%$ respectively. Rotenone (1\%) significantly affected the mortality of brood and adult bees whereas OA (3\%), did not. Solutions of 3\% OA/32\% sucrose, $3.4 \% \mathrm{OA} / 47.6 \%$ sucrose, $3.7 \% \mathrm{OA} / 27.1 \%$ sucrose $(\mathrm{w} / \mathrm{w})$ and a $32 \%$ sugar solution applied to adult bees resulted in death rates of $11 \%, 14 \%, 11.2 \%$ and $6.5 \%$ respectively. Individually treated bees consumed more of a $3 \%$ OA solution than solutions with higher OA concentrations. A TUNEL assay detected necrotic cell death in $69 \%$ of bee midgut cells $24 \mathrm{~h}$ after an OA treatment. Normal cell turnover is approximately $8 \%$.
\end{abstract}

Treatment / Apis mellifera / acaricide / TUNEL / cell death / mortality

\section{INTRODUCTION}

Varroa destructor Anderson and Trueman, an economically significant external parasite of honeybees (Anderson and Trueman, 2000), has to be controlled in order to ensure a colony's survival. Oxalic acid (OA) has been found to be effective against these mites in colonies both with and without brood (Nanetti and Stradi, 1997; Nanetti, 1999). A range of OA concentrations from $2 \%$ to $5 \%$ in $30 \%$ and $60 \%$ sucrose solutions (w/v) have been tested and their efficacy in honeybee colonies evaluated (Radetzki, 1994; Nanetti et al., 1995; Imdorf et al., 1997). Rotenone (1\%), the principal acaricidal constituent of derris root (Lonchocarpus nicou Aubl.), has also been used experimentally to control the varroa mite

Corresponding author: A. Gregorc,

Ales.Gregorc@kis.si

University of Maribor, Faculty of Agriculture, Vrbanska 30, 2000 Maribor, Slovenia.

* Manuscript editor: Jean-Noël Tasei in honeybee colonies (Jimenez et al., 2000; Gregorc and Poklukar, 2003). A number of reliable methods for evaluating the efficacy of acaricidal treatments, such as OA or rotenone, on bee colonies have been developed and widely used (Ritter, 1981; Fries et al., 1991; Gregorc and Jelenc, 1996; Poklukar, 1999; Gregorc and Planinc, 2001, 2002; Gregorc and Poklukar, 2003). A 3\% OA solution (w/v), applied with the trickling method, resulted in $5.6 \%$ and $12.6 \%$ of both young and old larvae being removed from comb cells by worker bees. After two treatments, the brood area was reduced by $17.5 \%$, while the brood area in control colonies increased by $34.5 \%$ (Hatjina and Haristos, 2005).

Accidental cell death is referred to as necrosis, whereas programmed cell death or apoptosis is described as designed (Bowen et al., 1996). Histochemical and immunohistochemical methods have established that programmed cell death occurs naturally during the development of honeybee larvae (Gregorc and Bowen, 
1997). This type of cell death can be induced by genetic means (White, 1996). Apoptosis is a particular form of programmed cell death such as in normal cell turnover, while necrotic cell death appears to be induced after a lethal accident or disease and under extreme conditions such as ischaemia, hypoxia, exposure to toxins and hyperthermia (Bowen et al., 1996). Apoptosis can be detected in situ using the terminal deoxynucleotidyl transferase mediated dUDP nick end labelling (TUNEL) method (Orita et al., 1999; Pulkkanen et al., 2000; Ortiz, 2003). This assay detects DNA breakdown preceding the collapse of apoptotic nuclei (Sgonc and Gruber, 1998). Programmed cell death in honeybees (Apis mellifera L.) has been revealed in the regressive hypopharyngeal glands (Moraes and Bowen, 2000) and in the midgut after a Paenibacillus larvae infection and an application of the acaricide amitraz (Gregorc and Bowen, 1998, 2000) as well as in the isolated atria of the heart after exposure to the herbicide 2,4-Dichlorophenoxyacetic acid (Papaefthimiou et al., 2002). It has also been shown that an OA solution becomes distributed throughout the digestive system of an adult worker bee within $24 \mathrm{~h}$ (Nanetti et al., 2002; Nozal et al., 2003) and, when applied directly onto bee larvae, has an adverse effect on the midgut at the cellular level (Gregorc et al., 2004). Investigations into the effects of $\mathrm{OA}$ and rotenone at the tissue and cellular level are important in order to monitor their modes of acaricidal action and to study any preclinical symptoms, as their introduction into a honeybee colony may cause injury to its population and, therefore, negatively impact upon its development. We used toxicological or immunohistochemical tests in order to establish: (1) the effects of OA and rotenone treatments on different stages of brood and their removal rate by worker bees after these treatments; (2) the mortality rates of caged adult worker bees following treatments of rotenone and various concentrations of OA solution; (3) the consumption levels of different OA solutions by individually confined worker bees; (4) the degree of necrotic cell death in the midgut of individually confined worker bees fed a 3\% OA solution ad libitum using apoptosis TUNEL assays.

\section{MATERIALS AND METHODS}

\subsection{In-hive brood treatments}

Twenty Apis mellifera honeybee colonies, populated in standard Slovenian hives with ten combs $(41 \mathrm{~cm} \times 26 \mathrm{~cm})$ in each brood and honey compartment, were located at the Agricultural Institute of Slovenia's experimental station in central Slovenia. Eight months before our experiment, the colonies were treated with Perizin (coumaphos), then equalised to occupy 6 to 8 brood combs per hive.

On the first day of the experiment (31st July, 2005), and prior to the treatments, A4-sized transparent sheets were placed over the brood in the central comb of each colony and the various developmental stages of the bees were recorded. The positions of cells containing eggs, larvae $<3$ days old larvae $=3$ days days old larvae and capped brood cells were marked red, green, blue and black, respectively. During each of the 3 examinations of the brood - 31st July, 7th August, 14th August, the same transparency was placed back over the comb and different symbols used to record the development of each cell. These results were then tabulated and statistically evaluated at the end of the experiment.

Five grams of $1 \%$ rotenone, which is $95 \%$ pure, was formulated with $99 \%$ bentonite as a neutral additive (both supplied by Sigma). The powder mix was sieved into each of the 6 colonies of Group 1 from above and onto the in situ bees and the top bars of the comb frames. Each of the 6 colonies of Group 2 was treated with $50 \mathrm{~mL}$ of an $3 \% \mathrm{OA} / 32 \%$ sucrose solution $(\mathrm{w} / \mathrm{w})$ prepared from $6.5 \mathrm{~g}$ OA dihydrate (Kemika, Zagreb, Croatia) and $50 \mathrm{~g}$ sucrose in 100 $\mathrm{mL}$ deionised water, which was distributed with a syringe $-5 \mathrm{~mL}$ into each of the 9 spaces between the combs and $2.5 \mathrm{~mL}$ into the 2 spaces formed between the $1 \mathrm{st}$ and 10th combs and the sides of the hives. The rotenone and OA treatments were performed on 31 st July. The 8 colonies of Group 3 were controls and received water only, which was applied using the same method as for the OA treatment. During the experiment the treatments were conducted in the brood compartments and the outside temperatures ranged between 28 and $30^{\circ} \mathrm{C}$.

\subsection{Caged worker bee treatments}

The worker bees used in these two experiments were taken directly from a colony and their numbers 
were approximated. The bees were brushed from the brood combs into $7.5 \mathrm{~cm} \times 4 \mathrm{~cm} \times 4 \mathrm{~cm}$ wooden cages that had been equipped with flasks for delivering both a $32 \%$ sugar solution and water ad libitum. Each cage had one side made of clear glass and another of wire mesh. The cages were kept in a dark room at $24( \pm 1){ }^{\circ} \mathrm{C}$ and dead bees were counted and removed every $12 \mathrm{~h}$.

\section{Experiment 1}

In the first experiment, 28 cages were populated with bees $(82.1 \pm 21.0)$ and divided into three groups. Nine cages were treated with $150 \mu \mathrm{L}$ of a $3 \% \mathrm{OA} / 32 \%$ sucrose in water solution $(\mathrm{w} / \mathrm{w})$, which was trickled in drops of $10 \mu \mathrm{L}$ through the mesh using a pipette according to Gregorc and Planinc (2001). Nine cages were treated with $30 \mathrm{mg}$ of the $1 \%$ rotenone/ $99 \%$ bentonite powder mix, which contained $0.285 \mathrm{mg}$ of pure rotenone, and was sieved through the mesh according to Gregorc and Poklukar (2003). The quantities of both substances were calculated according to the average number of bees per cage. This was done using the same "per bee" formula used when applying these substances to honeybee colonies in the field (Gregorc and Planinc, 2001) and after taking into consideration that the OA solutions would be applied directly onto in situ bees using a syringe rather than distributed randomly between the bees as would routinely occur under field conditions. Ten control cages were supplied with $150 \mu \mathrm{L}$ of a $32 \%$ sucrose solution per cage.

\section{Experiment 2}

In the second experiment, 25 cages were populated with bees $(95.4 \pm 17.9)$ and divided into 4 groups.

Six cages received $150 \mu \mathrm{L}$ of the $3 \% \mathrm{OA} / 32 \%$ sucrose solution; six cages received $150 \mu \mathrm{L}$ of a $3.4 \% \mathrm{OA} / 47.6 \%$ sucrose solution (10 g OA dihydrate, $100 \mathrm{~g}$ sucrose, $100 \mathrm{~g}$ water); seven cages received $150 \mu \mathrm{L}$ of a $3.7 \% \mathrm{OA} / 27.1 \%$ sucrose solution (7.6 g OA dihydrate, $38 \mathrm{~g}$ sucrose and $100 \mathrm{~g}$ water); six control cages received a $32 \%$ sugar solution. These $\mathrm{OA} /$ sucrose concentrations have been used during previous field research to reduce mite populations in honeybee colonies (Gregorc and Planinc, 2001).

\subsection{Individual worker bee treatments}

Four groups of 12 worker bees were removed manually from the capped brood of honeybee colonies. The bees were caged overnight without food then individually confined in $1.5 \mathrm{~mL}$ micro test tubes and provided with $20 \mu \mathrm{L}$ of a solution delivered by a micropipette attached to a tube that allowed ad libitum feeding. Group 1 was supplied with a 3\% OA/32\% sucrose solution (w/w) used in previous field researches conducted by Gregorc and Planinc $(2001,2002)$. Group 2 received a 3.7\% $\mathrm{OA} / 27.1 \%$ sucrose solution (w/w); Group 3 a $4.5 \%$ $\mathrm{OA} / 31.3 \%$ sucrose solution (w/w); and Group 4 received a $32 \%$ sugar solution. The $4.5 \%$ OA solution - $10 \mathrm{~g}$ OA dihydrate (Riedel-de Haën) and $50 \mathrm{~g}$ sucrose in $100 \mathrm{~g}$ water - was similar to solutions applied in Central European field experiments (Rademacher and Harz, 2006; Nanetti et al., 2003). Sucrose consumption was assessed 5, 20, and $24 \mathrm{~h}$ after the treatments, except in group 3 where it was measured only at $12 \mathrm{~h}$. After the 24 -h measurement, 3 live bee samples were taken from Group 1 and then prepared for immunohistochemical analyses to establish the mode of OA action and cell death rate in the midgut. Three live control bees were analysed for comparison. Concentrations higher than OA 3\% and $1 \%$ rotenone were not considered for the immunohistochemical analyses, since they resulted in adult mortality (Sect. 2.2).

\subsection{Immunohistochemical analyses}

The 3 bees individually treated with the $3 \%$ OA solution, as well as the 3 control bees, sampled from the previous experiment (Sect. 2.3), were dissected and their midgut fixed, dehydrated and embedded in paraffin wax (Gregorc and Bowen, 1999). The 7- $\mu \mathrm{m}$ sections were then deparaffinized and processed as per the instructions of the two kits used: the 'In situ cell death detection kit, AP' (ISCDDK) (Roche) and the 'DeadEnd colorimetric apoptosis detection system' (Promega). Cell death is a general term describing apoptosis and necrosis and Gregorc and Bowen (2000) showed that the two kits had different levels of sensitivity in detecting these two forms of cell deletion. The highly sensitive ISCDDK assay detects both in different tissues (Matylevitch et al., 1998), whereas the DeadEnd kit is more specific to apoptotic cell death.

Using the ISCDDK assay, tissue sections were incubated with proteinase $\mathrm{K}$ for $15 \mathrm{~min}$ and labelled with a 'TUNEL' reaction mixture. Any TdTenzyme-incorporated fluorescein was detected with 
Table I. Effects of in-hive brood treatments with a 3\% OA/32\% sucrose solution (w/w), a $1 \%$ rotenone powder mix and a control, water-only treatment during a 2-week trial beginning 31st July, 2005. Same letters indicate that Tukey tests $(P<0.05)$ established that the removal rates (after 7 days) or the replenishment rates (after 14 days) were not significantly different.

\begin{tabular}{|c|c|c|c|c|c|c|c|}
\hline \multirow{2}{*}{$\begin{array}{c}\text { Brood } \\
\text { stage - } \\
31 \text { July, } \\
2005\end{array}$} & \multirow{2}{*}{$\begin{array}{c}\begin{array}{c}\text { Brood cells } \\
\text { per comb - } \\
31 \text { July, 2005 } \\
( \pm \text { SD })\end{array} \\
\end{array}$} & \multicolumn{3}{|c|}{$\begin{array}{c}\text { Cells emptied } \\
\text { (after } 7 \text { days) } \\
\text { average } \% \pm \mathrm{SD}\end{array}$} & \multicolumn{3}{|c|}{$\begin{array}{c}\text { New brood in previously } \\
\text { emptied cells (after } 14 \text { days) } \\
\text { average } \% \pm \mathrm{SD}\end{array}$} \\
\hline & & $\begin{array}{l}\text { Rotenone } \\
(6 \text { colonies })\end{array}$ & $\begin{array}{c}\text { OA } \\
(6 \text { colonies })\end{array}$ & $\begin{array}{c}\text { Control } \\
(8 \text { colonies })\end{array}$ & $\begin{array}{l}\text { Rotenone } \\
(6 \text { colonies })\end{array}$ & $\begin{array}{c}\text { OA } \\
(6 \text { colonies })\end{array}$ & $\begin{array}{c}\text { Control } \\
(8 \text { colonies })\end{array}$ \\
\hline $\begin{array}{c}<3 \text {-day-old } \\
\text { larvae }\end{array}$ & $47.1 \pm 13.7$ & $\begin{array}{c}45.9 \pm 18.0 \\
b\end{array}$ & $\begin{array}{c}16.6 \pm 4.9 \\
\mathrm{a}\end{array}$ & $\begin{array}{c}9.6 \pm 9.4 \\
a\end{array}$ & $\begin{array}{c}14.6 \pm 26.5 \\
a\end{array}$ & $\begin{array}{c}0.0 \\
\mathrm{a}\end{array}$ & $\begin{array}{c}1.8 \pm 3.6 \\
\mathrm{a}\end{array}$ \\
\hline $\begin{array}{c}=3 \text {-day-old } \\
\text { larvae }\end{array}$ & $47.3 \pm 20.2$ & $\begin{array}{c}18.0 \pm 35.8 \\
\mathrm{a}\end{array}$ & $\begin{array}{c}25.3 \pm 35.1 \\
\mathrm{a}\end{array}$ & $\begin{array}{c}16.9 \pm 30.5 \\
\mathrm{a}\end{array}$ & $\begin{array}{c}47.6 \pm 52.3 \\
\mathrm{a}\end{array}$ & $\begin{array}{c}48.4 \pm 56.0 \\
\mathrm{a}\end{array}$ & $\begin{array}{c}100 \\
\mathrm{a}\end{array}$ \\
\hline $\begin{array}{c}\text { capped } \\
\text { brood }\end{array}$ & $\begin{array}{c}51.7 \pm 17.4 \\
b\end{array}$ & $\begin{array}{c}75.2 \pm 15.4 \\
\mathrm{a}, \mathrm{b}\end{array}$ & $\begin{array}{c}18.7 \pm 17.9 \\
\mathrm{a}\end{array}$ & $\begin{array}{c}13.3 \pm 23.1 \\
\mathrm{a}\end{array}$ & $\begin{array}{c}96.6 \pm 5.4 \\
\mathrm{a}\end{array}$ & $\begin{array}{c}100 \\
\mathrm{a}\end{array}$ & 100 \\
\hline
\end{tabular}

a 'converter-AP' consisting of an anti-fluorescein antibody and conjugated with alkaline phosphatase. The EnVision System alkaline phosphatase kit (Dako) was used to obtain a red coloured precipitate. The sections were counterstained with haematoxylin. TUNEL-positive cells, which are indicated by a reaction product localized to the nucleus and indicative of impending cell death, appeared red, whereas TUNEL-negative nuclei of healthy cells appeared blue. Control labelling was achieved by substituting the deoxynucleotidyl transferase (TdT) enzyme with phosphate buffered saline (PBS).

The DeadEnd kit labels fragmented DNA of apoptotic cells in situ using a TUNEL assay. After applying proteinase $\mathrm{K}$, the sections were incubated with the TdT reaction mixture and then with a horseradish-peroxidase-labelled streptavidin solution. Diaminobenzidine tetrahydrochloride (DAB) substrate was then applied onto the tissue sections to develop a brown reaction product. The sections were counterstained with methyl green. Control labelling was achieved by substituting the TdT enzyme with PBS.

In order to establish the percentage of cells affected by the treatment, approximately 70 cells from each of three tissue samples from the bees' midgut were selected randomly from microscopic object fields for TUNEL labelling. Light microscopy of the midgut epithelial cells and photography were conducted using a Nikon light microscope.

\subsection{Statistics}

We used ANOVA single factor analysis to test whether the treatments affected the bees. When necessary, this was followed by a Tukey test for pair wise comparisons. This method was applied to the mean values from the treatments in all our experiments. We used the Statgraphic plus (1996) software programme and considered $P=0.05$ as the significance threshold in all these statistical analyses.

\section{RESULTS}

\subsection{In-hive brood treatments}

The effects of the $3 \% \mathrm{OA} / 32 \%$ sucrose and the $1 \%$ rotenone treatments on the brood of honeybee colonies are presented in Table I and described in Sections 3.1.1-3.

\subsection{1. < 3-day-old larvae}

There were significant differences between the brood removal rates of the treatments $(\mathrm{F}=$ $10.6 ; \mathrm{df}=2 ; P<0.01)$ although no significant differences in the levels of brood replacement. 


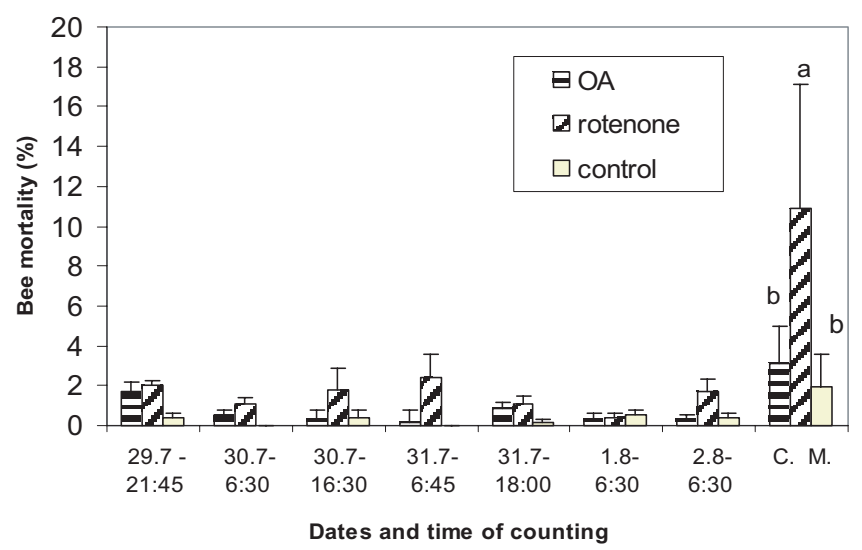

Figure 1. Mortality rates of caged bees after applications of a 3\% OA/32\% sucrose solution (w/w), a $1 \%$ rotenone $/ 99 \%$ bentonite powder mix and a 32\% sucrose control solution. Same letters indicate that Tukey tests $(P<0.05)$ established no significant differences between the cumulative mortality rates. (Bars $=$ standard deviation; $\mathrm{CM}=$ cumulative mortality).

While the OA treatments did not significantly affect the open brood removal rate, the removal rate in the rotenone-treated colonies was significantly higher than in those treated with OA $(P<0.05)$ and the controls $(P<0.01)$.

\subsection{2. = 3-day-old larvae}

The rotenone and $\mathrm{OA}$ treatments did not significantly affect the removal rate of the $=3$ day-old larvae $(\mathrm{F}=0.1 ; \mathrm{df}=2 ; P>0.05)$ nor the level of brood replacement $(\mathrm{F}=1.5$; $\mathrm{df}=$ 2; $P>0.05)$.

\subsubsection{Capped brood}

The treatments affected the removal rate significantly $(\mathrm{F}=13.5$; df $=2 ; P<0.01)$. Rotenone, OA and control groups resulted in $75.2 \%, 18.7 \%$, and $13.3 \%$ cell contents removed respectively. Rotenone affected capped brood significantly $(P<0.01)$ whereas OA did not.

Almost all the removed capped brood had been replaced with young brood within two weeks of each treatment (Tab. I).

\subsection{Caged worker bee treatments}

\section{Experiment 1}

The rotenone (1\%), 3\% OA/32\% sucrose $(\mathrm{w} / \mathrm{w})$ and $32 \%$ sugar solution treatments of the caged bees caused $10.9 \%( \pm 6.2 \%), 5.1 \%$ $( \pm 3.4 \%)$ and $1.9 \%( \pm 1.6 \%)$ bee mortality, respectively. The mortality rates of the three groups were significantly different $(\mathrm{F}=12.9$; $\mathrm{df}=2 ; P<0.001)$. The percentage of dead bees after the rotenone treatment was significantly higher $(P<0.001)$ than those of OA and control treatment. The OA did not significantly affect bee mortality (Fig. 1).

\section{Experiment 2}

In the second experiment, (Fig. 2) no significant difference was shown between mortality rates $(\mathrm{F}=2.7 ; \mathrm{df}=3 ; P>0.05)$.

\subsection{Individual worker bee treatments}

Statistical analyses showed (Tab. II) that the consumption rates of the 4 solutions $-3 \%$, $3.7 \%$ and $4.5 \% \mathrm{OA}$ and the control, sugar solution were significantly affected by the treatments $(\mathrm{F}=2.9$; $\mathrm{df}=3 ; P<0.05)$. Consumption was not affected significantly by the $3 \%$ OA solution after $5 \mathrm{~h}$ and $24 \mathrm{~h}$, but not after 


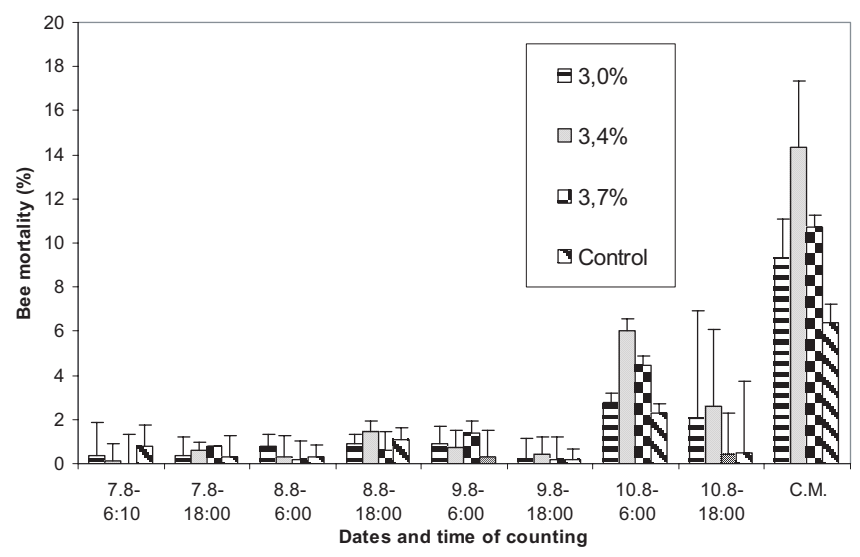

Figure 2. Mortality rates of caged worker bees after applications of $150 \mu \mathrm{L}$ of $3 \mathrm{OA} /$ sucrose solutions and a $32 \%$ sugar-in-water control solution on 6th August. No significant differences between the cumulative mortality rates were found using ANOVA single factor analyse. (Bars = standard deviation; $\mathrm{CM}=$ cumulative mortality).

Table II. Consumption of 3 different OA and a control sucrose solution by 4 groups of 12 individually confined worker bees. Same letters indicate that Tukey tests $(P<0.05)$ established no significant differences between the consumption rates. Figures are average solution intake in $\mu \mathrm{L}$ per bee \pm standard deviation.

\begin{tabular}{ccccc}
\hline & \multicolumn{3}{c}{ OA /sucrose concentration } & Control solution \\
\hline $\begin{array}{c}\text { Time Lapse } \\
(\mathrm{h})\end{array}$ & $3 \% / 32 \%$ & $3.7 \% / 27.1 \%$ & $4.5 \% / 31.3 \%$ & $32 \%$ sucrose \\
$(\mathrm{w} / \mathrm{w})$ & $(\mathrm{w} / \mathrm{w})$ & $(\mathrm{w} / \mathrm{w})$ & $(\mathrm{w} / \mathrm{w})$ \\
\hline 5 & $3.0 \pm 3.9$ & $1.7 \pm 2.1$ & $2.7 \pm 1.9 *$ & $4.9 \pm 3.9$ \\
& $\mathrm{~b}$ & $\mathrm{a}$ & $\mathrm{a}$ & $\mathrm{b}$ \\
20 & $5.5 \pm 2.7$ & $3.2 \pm 2.1$ & all bees dead & $9.2 \pm 6.0$ \\
& $\mathrm{a}$ & $\mathrm{a}$ & & $\mathrm{b}$ \\
24 & $6.9 \pm 2.0$ & $1.8 \pm 0.1$ & all bees dead & $7.1 \pm 5.1$ \\
& $\mathrm{~b}$ & $\mathrm{a}$ & & $\mathrm{b}$ \\
\hline
\end{tabular}

* Indicates consumption measured after $12 \mathrm{~h}$.

$20 \mathrm{~h}$, whereas at the two higher concentrations, OA solutions were significantly less consumed than the control solution at any time of the assessment $(P<0.05)$.

\subsection{Immunohistochemical analyses}

The ISCDDK kit showed that the 3\% OA treatment resulted in a significant increase of cell death rate in the midgut epithelium, compared to the control $69 \%$ and $29 \%$ respectively (Tab. III), whereas the DeadEnd kit did not reveal a significant difference $(P>0.05)$ be- tween treated and control bees $(9 \%$ and $8 \%$ cell death respectively). Both kits also differed significantly when the control bees were analysed $(P<0.05)$. Compared to the bees treated with the sugar-only solution, the morphology of the epithelium was unchanged.

\section{DISCUSSION}

\subsection{In-hive brood experiments}

Only the $1 \%$ rotenone treatment of the colonies significantly increased the removal 
Table III. Level of epithelial cell death in the midgut of individually confined worker bees detected by 2 different immunohistochemical assay kits $24 \mathrm{~h}$ after treatment with either a 3\% OA application or a control, sugar solution. Same letters indicate that Tukey tests $(P<0.05)$ established no significant differences between the cell death rates (small letters) or the sensitivity of the kits (capital letters). $\mathrm{SD}=$ standard deviation.

\begin{tabular}{cc}
\hline $\begin{array}{c}\text { Level of cell death after } 24 \mathrm{~h} \\
(\% \pm \mathrm{SD})\end{array}$ \\
\hline ISCDDK & DeadEnd \\
\hline $69 \pm 4.8$ & $9 \pm 3.9$ \\
a, A & b, B \\
\hline Control & Control \\
\hline $29 \pm 1.4$ & $8 \pm 2.1$ \\
b, A & b, B \\
\hline
\end{tabular}

rates of <3-day-old larvae and capped brood from the comb cells. Nevertheless, in good weather and pasture conditions, the emptied brood cells can be replenished by an egglaying queen and thus the colony is not weakened. Increased levels of brood mortality were found after two $2.4 \% \mathrm{OA} / 48.3 \%$ sucrose $(\mathrm{w} / \mathrm{w})$ treatments $(3 \%$ OA w/v) (Hatjina and Haristos, 2005) and according to Higes et al. (1999) a 3\% OA in water solution (w/v) resulted in a significant long-term negative effect on brood and colony development. Various application methods and concentrations of $\mathrm{OA}$ and sugar solution have been employed to control varroa mites in honeybee colonies. Concentrations of approximately $3 \%$ OA and up to $60 \%$ sugar-in-water solutions $(\mathrm{w} / \mathrm{v})$ could be used in colonies during the brood period to minimize both the negative impact of varroa mites and the detrimental effects of the treatment on the existing brood (Hatjina and Haristos, 2005). Brood mortality following the rotenone treatment indicates that it has a toxic effect. Topical applications of $3 \mu \mathrm{L}$ of highly concentrated OA (20\% and $10 \% \mathrm{w} / \mathrm{v})$ resulted in increased levels of OA in internal organs (Nozal et al., 2003). The quantities of OA received by each bee or the brood after it was trickled into the colonies was not in- vestigated, although the distribution among the bees and, therefore, their mortality rate, was unlikely to have been uniform as bees at the top of the hives were more exposed to the treatment using this method.

\subsection{Caged and individual bee treatments}

The $1 \%$ rotenone treatment of the caged bees resulted in a higher mortality rate than the $3 \% / 32 \%, \mathrm{OA} /$ sucrose solution. Bee mortality increased, albeit insignificantly, after applying a $3 \%$ OA concentration widely used in our previous field experiments (Gregorc and Planinc, 2001, 2002). The mortality rate after the $3.4 \% \mathrm{OA} / 47.6 \%$ sucrose and the $3.7 \%$ $\mathrm{OA} / 27.1 \%$ sucrose solutions treatments remained insignificantly higher during the experiment in comparison to $3 \% \mathrm{OA}$ and control treated bees. Our experiment has shown that a $3 \% \mathrm{OA} / 32 \%$ sucrose solution does not significantly affect bee broods and adult bees, whereas a $1 \%$ rotenone powder mix does. Worker bees prefer drinking a 3\% OA solution rather than more concentrated OA solutions. Nevertheless, considering the immunohistological test following the 3\% OA application we assume that overdosing is likely to induce detrimental effects on adult bees. This aspect is of great practical importance in beekeeping, particularly as the $4.5 \% / 31.3 \%$ OA solution consumed by the individually confined and fed bees caused death after ad libitum feeding, not with standing the effect of isolation on bee longevity. The quantity of OA received by individual bees after it was trickled into the cages was not investigated.

\subsection{Cell death}

Normal cell turnover usually ranges between 5\% and 10\% (Gregorc and Bowen, 1997; Gregorc et al., 2004) which is consistent with the $8 \%$ cell death found in the control tissue when using a DeadEnd kit. Using an ISCDDK assay Gregorc and Bowen (2000) 
found that amitraz - another acaricide - increased the level of cell death in bee larvae and that an OA application triggered necrotic cell death in the midgut (Pulkkanen et al., 2000). Using this assay, we established the level of epithelial cell death in the midgut caused by a $3 \%$ OA application to an individual adult bee was $69 \%$ after $24 \mathrm{~h}$ which was $40 \%$ more than the control.

The increased level of cell death after the OA application indicates that it has an injurious effect on individual worker bees at a cellular level, although this does not necessarily lead to an increase in bee mortality. Apart from the midgut, it was demonstrated by Silva-Zacarin et al. (2006) that other internal larval organs such as the salivary glands, show varying degrees of morphological cellular alteration and increased levels of cell death after treatment with OA. The application of our 3\% OA solution triggered an increase in midgut cell death in the individually treated bees whereas it was not shown that $3 \%$ OA or control solution feeding affected significantly adult bee mortality. At this stage, it is not possible to correlate cell death found in the midgut epithelial cells with larvae or adult bee mortality, nor is it known what concentrations of rotenone or OA do not have detectable adverse effects on brood or adult bees at the cellular level. Further experiments should be conducted to establish the relationship between cell death detected with immunohistochemical diagnostic tools and the presentation of clinical symptoms and mortality in worker bees. The observations made and testing methods we used, both in the field and in the laboratory, are powerful diagnostic tools that should be explored further in future research at the colony, cellular and tissue levels to evaluate the threshold effects of substances used in bee colonies.

\section{ACKNOWLEDGEMENTS}

We would like to thank Matjaž Golc for his technical assistance. This work was supported by the Slovenian Ministry of Higher Education, Science and Technology (Research programme P4-133 and project: L7-7602-0401) and the Ministry of Agriculture, Forestry and Food (No. V4-0759-0406-02).
Examen toxicologique et immunohistochimique d'abeilles domestiques (Apis mellifera) ayant été traitées à l'acide oxalique et à la roténone.

Apis mellifera / traitement / acaricide / mortalité / mort cellulaire / méthode TUNEL

Zusammenfassung - Toxikologische und immunohistochemische Untersuchungen an Oxalsäure- und Rotenon-behandelten Honigbienen. Wir führten vier unterschiedliche Experimente und eine immunohistochemische Analyse an Honigbienenvölkern durch, um die Effekte von zwei Akariziden besser zu charakterisieren. Sowohl Oxalsäure (OA) als auch Rotenon werden gängigerweise zur Kontrolle der ektoparasitischen Milbe Varroa destructor eingesetzt. Im ersten Experiment wurden 12 Apis mellifera Völker mit einer 3 \% OA-Lösung oder mit Rotenon (1\%, in Pulverform) behandelt, um den Einfluss dieser Applikationen auf die Brutentwicklung zu untersuchen.

Im zweiten Experiment wurden diese Akarizide an gekäfigten Arbeiterinnen (18 Versuchsansätze) im Hinblick auf ihre Toxizität (Mortalität) getestet. In einem dritten Experiment untersuchten wir ebenfalls die Mortalitätsraten in 19 Käfigen mit Arbeiterinnen, denen jeweils eine der folgenden OA/Sacharose-Lösungen verabreicht wurde: $3 \% / 32 \%$; $3,4 \% / 47,7 \%$; oder $3,7 \% / 27,1 \%$. Im vierten Experiment erhielten 36 Arbeiterinnen in Einzelhaltung jeweils eine der folgenden OA/Sacharose-Lösungen: $3 \% / 32 \% ; 3,7 \% / 27,1 \%$ oder $4,5 \% / 31,3 \%$. Für diese ad libitum über eine 24-Stunden Periode verabreichten OA/SacharoseLösungen wurden die Aufnahmeraten bestimmt. Für die Bienen, die im vierten Experiment eine $3 \%$ OA-Lösung erhalten hatten, bestimmten wir anschliessend den Grad der durch die Behandlung verursachte Gewebeschädigung im Mitteldarm. Dazu wurde der herauspräparierte Darm zwei immunohistochemischen Tests unterzogen. Spezifische Ziele dieser Arbeit waren die Bestimmung (a) der Effekte der OA- und Rotenon-Behandlungen auf die Brutstadien, (b) der Mortalitätsraten als Folge unterschiedlicher OA oder Rotenon-Behandlungen, (c) der Aufnahmeraten für unterschiedliche OA-Konzenrationen und (d) der Effekte einer OA-Behandlung auf Zelltod in Arbeiterinnen.

Die Ergebnisse waren, dass nach der RotenonBehandlung mehr Brut entfernt wurde $(75,2 \%)$ als nach der $3 \%$ OA-Behandlung $(18,7 \%)$ (Tab. I). Die Rotenon-Behandlung im zweiten Experiment zeigte eine signifikant erhöhte Mortalität dieser Bienen (Abb. 1). Im dritten Experiment fanden wir für die mit der 3,4 \% und der 3,7 \% OA-Lösung behandelten gekäfigten Bienen eine signifikant erhöhte Mortalität (Abb. 2). Im vierten Experiment zeigte sich, dass die Bienen die $3 \%$ OA-Lösung 
den anderen bevorzugten (Tab. II). Die immunohistochemischen Untersuchungen an Bienen, die im vierten Experiment über 24 Stunden hinweg eine 3 \% OA-Lösung erhalten hatten, zeigten Anzeichen von natürlichem (apoptotischem) oder verletzungsbedingtem (nekrotischem) Zelltod in $69 \%$ der Zellen des Mitteldarms. Der normale Zellumsatz in diesem Gewebe liegt bei $8 \%$ (Tab. III).

Während die Wirksamkeit sowohl von Rotenon als auch OA zur Bekämpfung der Varroamilbe unbestritten ist, sollten dennoch die Faktoren Jahreszeit - d.h. ob Brut vorhanden ist oder nicht - und Konzentration der OA-Lösungen berücksichtigt werden, um eine ökonomisch optimale Wirkung an den Bienen eines Volkes zu erzielen. Wir denken, dass unsere Untersuchungen hierzu eine Beitrag leisten konnten.

Behandlung / Apis mellifera / Akarizide / TUNEL / Zelltod

\section{REFERENCES}

Anderson D.L., Trueman J.W.H. (2000) Varroa jacobsoni (Acari: Varroidae) is more than one species, Exp. Appl. Acarol. 24, 165-189.

Bowen I.D., Mullarkey K., Morgan S.M. (1996) Programmed Cell Death during Metamorphosis in the Blow-Fly Calliphora vomitoria, Microsc. Res. Tech. 34, 202-217.

Fries I., Aaehus A., Hansen H., Korpela S. (1991) Comparison of diagnostic methods for detection of low infestation levels of Varroa jacobsoni in honey-bee (Apis mellifera) colonies, Exp. Appl. Acarol. 10, 279-287.

Gregorc A., Jelenc J. (1996) Control of Varroa jacobsoni Oud. in honeybee colonies using ApilifeVAR, Zb. Vet. Fak. Univ. Ljubljana 33, 255-259.

Gregorc A., Bowen I.D. (1997) Programmed cell death in the honeybee (Apis mellifera L.) larvae midgut, Cell. Biol. Int. 21, 151-158.

Gregorc A., Bowen I.D. (1998) Histopathological and histochemical changes in honeybee larvae (Apis mellifera L.) after infection with Bacillus larvae, the causative agent of American foulbrood disease, Cell. Biol. Int. 22, 137-144.

Gregorc A., Bowen I.D. (1999) Heat-shock and histone group protein expression in honey-bee larvae infected with Paenibacillus larvae, Cell. Biol. Int. 23, 211-218.

Gregorc A., Bowen I.D. (2000) The histochemical characterisation of cell death in honeybee larvae midgut after treatment with Paenibacillus larvae, Amitraz and Oxytetracycline, Cell. Biol. Int. 24, 319-324.
Gregorc A., Planinc I. (2001) Acaricidal effect of oxalic acid in honeybee (Apis mellifera) colonies, Apidologie 32, 1-8.

Gregorc A., Planinc, I. (2002) The control of Varroa destructor using oxalic acid, Vet. J. 163, 306-310.

Gregorc A., Poklukar J. (2003) Rotenone and oxalic acid as alternative acaricidal treatments for Varroa destructor in honeybee colonies, Vet. Parasitol. 111, 351-360.

Gregorc A., Pogaènik A., Bowen I.D. (2004) Cell death in honeybee larvae treated with oxalic or formic acid, Apidologie 35, 453-460.

Hatjina F., Haristos L. (2005) Indirect effects of oxalic acid administered by trickling method on honey bee brood, J. Apic. Res. 44, 172-174.

Higes M., Meana A., Suarez M., Llorente J. (1999) Negative long-term effects on bee colonies treated with oxalic acid against Varroa jacobsoni Oud. Apidologie 30, 289-292.

Imdorf A., Charriere J.D., Bachofen B. (1997) Efficiency checking of Varroa jacobsoni control methods by means of oxalic acid, Apiacta 32, 89-91.

Jimenez J.J., Bernal J.L., Nozal M.J., Novo M., Higes M., Llorente J. (2000) Determination of rotenone residues in raw honey by solid-phase extraction and high-performance liquid cromatography, J. Chromatogr. A 871, 67-73.

Matylevitch N.P., Schuschereba S.T., Mata J.R., Gilligan G.R., Lawlor D.F., Goodwin C.W., Bowman P.D. (1998) Apoptosis and accidental cell death in cultured human keratinocytes after thermal injury, Am. J. Pathol. 153, 567-577.

Moraes R.L.M.S., Bowen I.D. (2000) Modes of cell death in the hypopharyngeal gland of the honey bee (Apis mellifera L.), Cell. Biol. Int. 24, 734-737.

Nanetti A. (1999) Oxalic acid for mite control - results and review. Coordination in Europe of research on integrated control of Varroa mites in honey bee colonies, Commission of the European communities, concerted action 3686, 7-14.

Nanetti A., Stradi G. (1997) Varroosis: chemical treatment with oxalic acid in sugar syrup, Ape Nostra Amica 19, 6-14.

Nanetti A., Massi A., Mutinelli F., Cremasco S. (1995) L'acido ossalico nel controllo della varroasi: note preliminari, Apitalia 22, 29-32.

Nanetti A., Ghini S., Gattavecchia E., Bartolomei P., Marcazzan G.L., Massi S. (2002) Pharmacodynamics of oxalic acid and treatment residues in honey, Symp. Apimondia "Prevention of residues in honey", Celle (Germany), October 2002, session brochure, pp. 10-11. 
Nanetti A., Buchler R., Charriere J.D., Fries I., Helland S., Imdorf A., Korpela S., Kristiansen P. (2003) Oxalic acid treatments for varroa control (review), Apiacta 38, 81-87.

Nozal M.J., Bernal J.L., Gomez L.A., Higes M., Meana A. (2003) Determination of oxalic acids in honey and in some anatomic structures of bees, Apidologie 3, 181-188.

Orita Y., Nishizaki K., Sasaki J., Kanda S., Kimura N., Nomiya S., Yuen K., Masuda Y. (1999) Does TUNEL staining during peri- and post-natal development of the mouse inner ear indicate apoptosis? Acta Otolaryngol. Suppl. 540, 22-26.

Ortiz A. (2003) Staining for cell death, The Lancet 361, 1748.

Papaefthimiou C., Pavlidou V., Gregorc A., Theophilidis G. (2002) The action of 2,4dichlorophenoxyacetic acid on the isolated heart of insect and amphibia, Environ. Toxicol. Pharmacol. 11, 127-140.

Poklukar J. (1999) Influence of queen mothers on the honeybee hive varroa mite population in the year 1998, Zb. Bioteh. Fak. Univ. Ljubljani. Kmetijstvo, Zootehnika 74, 57-63.
Pulkkanen K.J., Laukkanen M.O., Naarala J., YlaHerttuala S. (2000) False-positive apoptosis signal in mouse kidney and liver detected with TUNEL assay, Apoptosis 5, 329-333.

Rademacher E., Harz M. (2006) Effectiveness of oxalic acid for controlling the Varroa mite, Am. Bee J. $146,614-617$.

Radetzki T. (1994) Oxalsäure eine weitere organische Säure zur Varroabekämpfung, Allg. Dtsch. Bienenztg. 12, 11-15.

Ritter W. (1981) Varroa disease of the honeybee Apis mellifera, Bee World 62, 141-153.

Sgonc R., Gruber J. (1998) Apoptosis detection: an overview, Exp. Gerontol. 33, 525-533.

Silva-Zacarin E.C.M., Gregorc A., Silva de Moraes R.L.M. (2006) In situ localization of heat shock proteins and cell death labelling in the salivary gland of acaricide-treated honey bee larvae, Apidologie 37, 1-9.

Statgraphic plus (1996) Statistical graphic system, STSC, Rockville.

White E. (1996) Life, death and the pursuit of apoptosis, Genes Development 10, 1. 